\title{
The Late Abbott Lawrence Rotch
}

\section{A Pioncer Investigator in Aerology}

\section{By Andrew H. Palmer, A.M., Research Assistant, Blue Hill Observatory}

I F there is one science in which the United States has 1 stood on a par with European nations in its contributions it is meteorology, the science of the atmosphere. It is no exaggeration of the truth to say that no other single nation can boast of a more formidable list of pioneer investigators in one branch of knowledge. In meteorology America is rightly proud of such men as Ferrel, Loomis, Espy, Redfield, Henry, Abbe and Rotch. Each has been associated with one particular field of research and each has left his name indelibly stamped upon the facts and principlez he helped to determine. It is with the man whose name is quoted last in the foregoing list that this sketch is concerned. At the time of his death, on April 7th last, he was not only America's most prominent exponent in acrology, that branch of meteorolgy which deals with the free air aloft, but also among the half-dozen leading aerologists of the world.

Abbott Lawrence Rotch was born in Boston, January 6th, 1861. His training was received through private tutors, foreign travel, and at the Massachusetts Institute of Technology, from which he was graduated in 1884, receiving the S.B. degree. Just as every other intelligent young man has a particular field of knowledge to which his fancy turns, so Rotch became interested in meteorology, partly as a result of his attendance at the Saturday night round-table conferences of the Boston Scientific Society and the frequent meetings of the New England Meteorological Society. Born to an aristocracy of wealth as well as of genius, Mr. Rotch visited the more prominent European observatories in 1884 and 1855, and in the latter year established Blue Hill Meteorological Observatory on the summit of Great Blue Hill, 635 feet above the sea-level, and ten miles south of Boston. The history of the observatory is really a biography of its founder, so closely are the two related. From its very beginning the progress of the observatory was marked by innovations, as far as America was concerned, which have since been widely adopted. To quote Prof. Frank Waldo, "There can be no doubt that the work of Blue Hill Observatory has had a very great quickening influence in the recent developments in observational meteorology in this country. Not only has its thoroughly independent attitude and scientific spirit enabled it to make usefulness and not policy its watchword, but it has also permitted it to improve the older traditions of American meteorology, by adding to them the best features of European meteorology." The newly established institution was equipped with self-recording instruments which in variety and completeness even excelled the older Draper Observatory in Central Park, New York city. The successful use of automatically recording instruments so impressed Gen. Hazen, the chief signal officer, when he visited Blue Hill in 1886, that they were soon officially adopted and have since been in use in gov ernment stations throughout the country. The observatory very early undertook the issue of local weather forecasts, which were printed in the Boston newspapers. Their success also impressed the government; for they were adopted by the Signal Service, only general or regional forecasts having been attempted by the governrejional forecasts having been attempted by the govern-
ment up to that time. It is not generally known that the cyclo-style weather maps which have given to the public a graphic representation of the weather conditions each day over the whole United States, were first issued privately in May, 1886, from the Boston Signal Service station by Messrs. Cole and Rotch at the latter's expense. The observatory also led the way by means of a good example in the use of the international form of publication of weather data and in the employment of the metric system of units wherever possible.

But it is through its contributions to aerology that Blue Hill Observatory has won enduring fame. Here on August 4th, 1894, the first registering meteorological instrument was sent aloft by means of a kite. Since that date more than a thousand successful soundings have been made, and the instrument has at times been lifted to heights greater than three miles above the earth. The honor of making the first thorough exploration of the lower mile of free air belongs to the observatory. The

kite method of aerial sounding has since been adopted all over the civilized world, and on twenty-three predetermined days each year flights are made at forty different stacions, while some, like the Mount Weather Observatory of the United States Weather Bureau, have daily kite flights throughout the year. Both the method of observation as well as much of the apparatus in use at the present time have direct precedents in the experiments on Blue Hill. Mr. Rotch also conducted the first American researches with sounding-balloons-small, hydrogen-filled rubber bags carrying recording instruments which are brought back to the ground by means of parachutes after ascending to heights of ten to fifteen miles. He was also the first one in this country to use the pilot-bal!oon to determine wind velocity and direction aloft by means of trigonometrical observations. Both

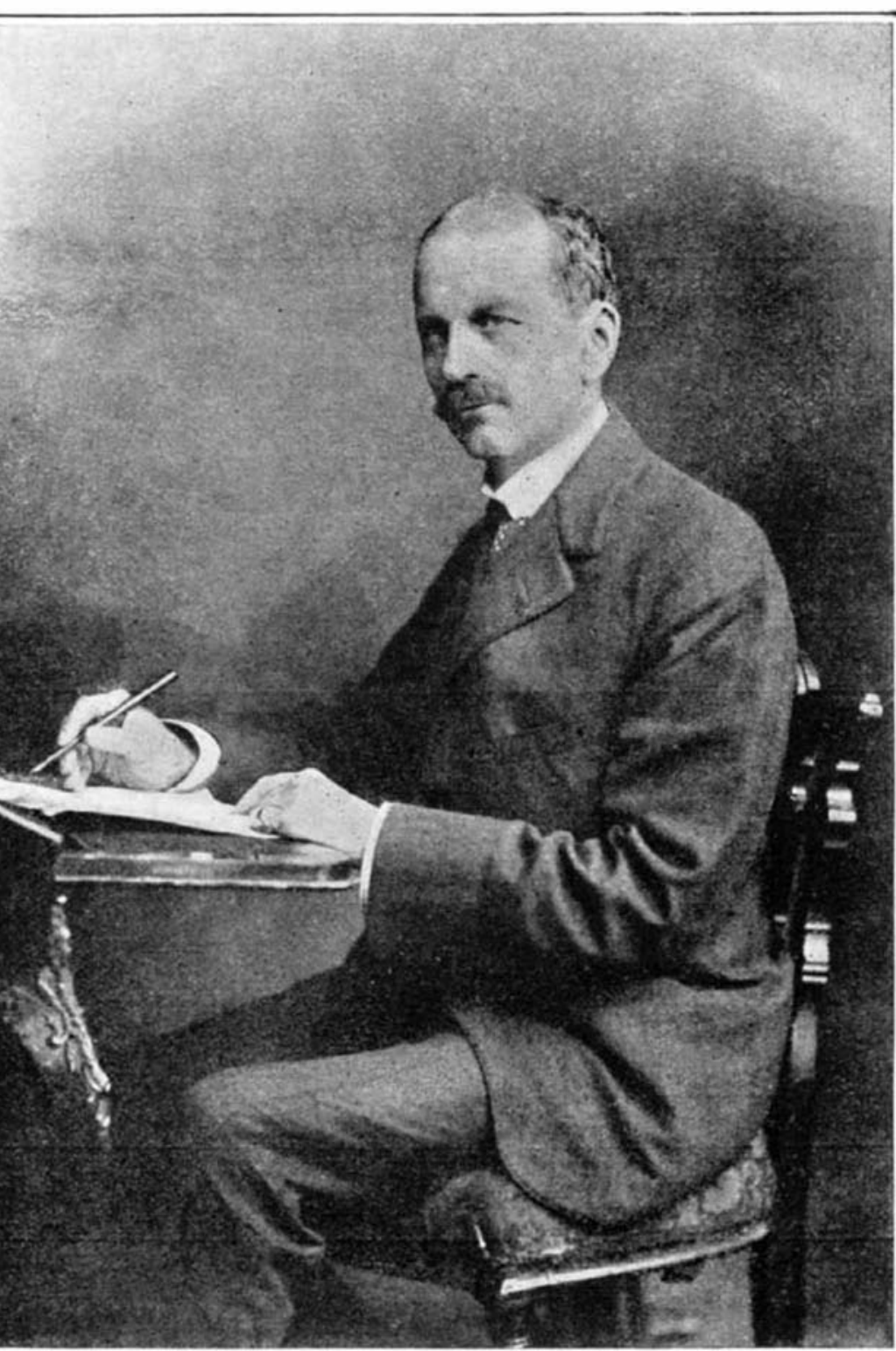

THE LATE A. LAWRENCE ROTCH

places to advance our knowledge of the atmosphere on land as well as above the sea. The most notable of the latter was his association with MM. L. Teisserene de Bort in 1905 to 1906 when an expedition was sent to study the trade winds of the tropical Atlantic. Just before his last and only illness he was making plans to co-operate in the proposed Crocker Land expedition, his interest again reverting to the meteorological considerations. Not realizing that death was so near he had engaged passage in order to attend the seventh meeting of the International Commission for Scientific Aeronautics, from whose gatherings he was never absent.

Of recent years Prof. Rotch's a ttention has naturally turned to aeronautics. Having made several balloon voyages while abroad, and because of his thorough knowledge of kites and of the air aloft, his opinions were frequently sought by experimenters, and among his correspondents were many prominent in aviation, both at home and abroad. He was president of the Harvard Aeronautical Society and a governor of the Aero Club of America. Capt. Moedebeck, who until his death two years ago was the leading German authority on aerial navigation, referred to Prof. Rotch as one of the two Americans who did the pioneer aerological investigation which has rendered possible the remarkable progress in the art of aerial navigation during the last decade. In the midst of his researches Prof. Rotch found time to lesture occasionally, while his contributions to periodicals number over two hundred titles. He was also the author of "Sounding the Ocean of Air," 1900, "The Conquest of the Air," 1909 and, with the writer of this sketch, published the "Charts of the Atmosphere" less than a year ago.

Though a member of clubs in Boston, New York and Washington, Prof. Rotch was essentially a home man, and divided his time between his home and the observatory. Prof. Rotch's dominant interest was Blue Hill Observatory and the science with which it was concerned. In accordance with his last will and testament the property, with an endow ment of $\$ 50,000$, becomes the property of Harvard University. In one of his last papers he wrote, "It is to be hoped that the observatory may have its existence prolonged, with unchanged environments and methods of observation, to the close of the century; but since this transcends the life of one individual, the duty mist devolve on the university to which it is allied."

The castle-like structure which crown the summit of Great Blue Hill remains a fitting monument to a great life-work. Of its record, which may properly be considered the founder's contribution to knowledge, Prof. Waldo writes, "I venture to express the opinion that when the history of meteorology during the latter half of the nineteenth century is written, the Blue Hill

forms of balloons are now used by the United States Weather Bureau. It is obvious from the foregoing facts that the observatory has been especially strong in the experimental field of pure science and in the development of new methods of observation, activities which a government service can not undertake when narrow-minded legislators continually demand immediate results.

A man of Rotch's caliber does not regard personal honors in the same light with which the layman view them. They came unsolicited to him, however. Harvard conferred upon him the honorary A.M. degree in 1891 and made him professor of meteorology in 1906 He was a member of practically every honorary scientific society of national importance. "A prophet is not without honor, save in his own country," however, and he was better known among the scientists of Europe than among those at home, and was an honorary member of many foreign learned societies. While a member of the International Jury of Awards at the Paris Exposition in 1889 he was made Chevalier of the Legion of Honor. On him were also conferred the Prussian Order of the Crown in 1902 and the Order of the Red Eagle in 1905. Hi chief delight was that of participating in scientific in sestigations. He served on the International Solar and Aeronautical Commissions from their very inception, an co-operated with various expeditions sent to distant Observatory will be assigned the foremost place in American observational meteorology, and this judgment will be based not only on the observations which have been made, but also on their proper discussion and correlation with allied branches of this science of the atmosphere."

\section{American Railways in Uruguay}

A CCORDING to the London Times, the first conces $\mathbf{A}_{\text {sion obtained by American capital to build railways }}$ in Uruguay, has led to the active berinning of work on a line that is to run from Colonia (where a fully equipped modern port will be built), opposite Buenos $\Lambda$ ires, almost due north to San Luis, on the northern frontier, where it will be linked up with the Brazilian system. This line, known as the Trans-Uruguayan, which with its branches will have a mileage of 425 , forms part of a network which it is proposed to carry over virtually the whole continent of South $\Lambda$ merica. Negotiations are now nearly complete for another line, in which American capital is interested, to run from Coronilla, on the Atlantic Ocean, where also a port will 've built, to Santa Rosa, on the Uruguay River. This line, like the other, is but the initial step in a system that is expected to ramify into Brazil, $\Lambda$ rgentina and Paraguay. 